\title{
Consumption Behavior of Santri in Islamic Boarding School (Study at Darussalam Martapura Islamic Boarding School)
}

\author{
Muhammad Rahmattullah ${ }^{*}$ Hildayati $^{1}$ \\ ${ }^{I}$ Economic Education Department, Faculty of Teacher and Training, Lambung Mangkurat University, Banjarmasin, \\ Indonesia \\ ${ }^{*}$ Corresponding author.Email: mrahmattullah@ulm.ac.id
}

\begin{abstract}
This research is intended to analyze the consumption behavior of santri in Darussalam Martapura Islamic boarding school. This research uses a qualitative research approach and the type of research is field research. Primary data collection techniques were obtained through in-depth interviews, observation, and documentation. The data analysis technique used in this study is the Spradley model. The key informant in this study was santri Darussalam Martapura boarding school. The results show that santri consumption behavior tends to be wasteful with studies on social, cultural, personal, and psychological aspects. Findings on the implementation of the concept of planning, the concept of priority scale (recording), the concept of income, and the concept of expenditure relating to the behavior of implusive buyers and patient buyers of each santri.
\end{abstract}

Keywords: Behavior, comsumption, santri.

\section{INTRODUCTION}

Humans are essentially economic people. Economic man in Latin namely homo economicus means human figure who is rational and free in determining the choices that exist to achieve certain goals. Every human behavior must be more rational and choose existing resources [1].

Humans in everyday life need economics that provides a role to calculate the burden of needs and income so that their use in life becomes more effective and efficient. One study of economics is the production, distribution and consumption activities. Production is an activity to produce goods or services or add value to an item or service. This distribution has something to do with how these goods can reach consumers. Distribution is an economic activity that highlights production and consumption activities. Consumption is an activity utilizing goods or services in meeting the needs of life (Suhardi, 2016).

According to Engel et al [2], consumer behavior is an action that is directly involved in the acquisition, consumption, and end of product/service, including the process that precedes and composes this action. Consumer behavior is defined as a study of purchasing units and exchange processes that involve planning, consumption and manufacturing, goods, services, experiences, and ideas [3]. Consumption behavior is more likely for consumers to consume. In other words, consuming is the behavior of consumers, where they can illustrate the search to buy, use, evaluate, and improve their products and services. Consumption behavior can be divided into three types namely Impulsive Buyers are consumers who want to quickly buy, tend to be careless in consuming the products offered. Patient Buyers are conscientious consumers who make price comparisons and analyze the products offered. Window Shoppers are consumers who are just browsing or just surfing [4].

Kotler [5] Factors that influence consumer behavior are cultural, social, personal, psychological factors. Some of these factors are not considered by marketers but actually must be taken into account to determine how far those factors of consumer behavior affect consumer purchases (Suhardi, 2016).

Consumer behavior factors are manifestations of human behavior that is very complex and comprehensive, this is caused by the many variables that influence consumer behavior with a tendency to interact with each other. According to [6] there are 4 factors that influence consumer purchasing decisions, namely: Cultural factors include culture, sub-culture, social class. Social factors include reference groups, family, role and status. Personal factors include age, occupation, economic circumstances, lifestyle, personality. Psychological factors include motivation, perception, learning process, beliefs and attitudes. South Kalimantan is one of the provinces in Indonesia.

South Kalimantan Province has an area of $37,530.52 \mathrm{~km} 2$ with a population of almost 3.7 million people. South Kalimantan has 11 districts and 2 cities. Based on data that the majority of religions in South Kalimantan are Islam with 96.23\% Islamic presentation division, Hindu 1.61\%, Protestant Christian 1.26\%, Catholic 0.57\%, and Buddhist $0.33 \%$.

The large presentation of Islam in South Kalimantan has led to the discovery of schools with the concept of Islamic boarding schools with more learning about Islam than general lessons. The existence of pesantren as an Islamic 
educational institution has been formally recognized and has become an integral part of the subsystem of the national education system. This is specifically regulated in Law No. 20 of 2003 concerning the National Education System which states that pesantren are religious education institutions whose function is to prepare students to become members of the community who understand and practice the values of religious teachings [7].

One of the largest Islamic boarding schools in South Kalimantan is the Darussalam Martapura boarding school. Darussalam Islamic Boarding School is a boarding school located in the area of Pasayangan, Martapura, Banjar Regency, South Kalimantan, Indonesia. This boarding school was founded in 1914 by K.H. Jamaluddin, one of the leading scholars at the time, was the founder and first leader of the Darussalam pesantren [8]. The learning system in Darussalam boarding schools uses the yellow book curriculum with material religious values [9].

The situation that occurred in the field was found that Islamic boarding schools had santri who behaved consumptively and some behaved appropriately. Santri who behave consumptively because of the influence of social status, playmates, fulfillment of desires not needs, are consumed by the promotion of a product, wasteful personal self, likes something instant, often owes, does not make priority scale, has the principle if "income rises then expenses will go up ", buy something just for the prestige event, and an understanding of consumption behavior that is still poorly understood by santri (2020 research data source).

Based on the results of the pre-survey and several supporting theories a temporary conclusion can be made namely the consumption behavior of santri in Darussalam Islamic boarding schools tends to be wasteful. Previously there had never been any research that examined the behavior of santri in Darussalam boarding schools. So that researchers want to conduct in-depth research to analyze the lives of santri in their consumption behaviour.

\section{RESEARCH METHODS}

The approach used in this study is a qualitative approach. The approach is used to identify consumption behavior in santri in Islamic boarding schools. In addition, the qualitative approach is expected to reveal the situation and problems encountered in economic activities there. This type of research includes field research.

The presence of researchers in this study serves as an observer and interviewer. So that the implementation of this study involved researchers directly in the field to see how consumption behavior in studens in Islamic boarding schools. The locations taken in this study are Martapura City, Cindai Alus, Kec. Martapura, Banjar, South Kalimantan. This location was chosen as the object of research because there is a boarding school. The subjects in this study were santri in Darussalam boarding school, Martapura. The number of informants is 12 santri with different levels.

The following is a list of respondents used in this study: Diniyah Awaliyah: Kurniawan (two awaliyah), Muhammad
Akbar (four awaliyah), Anida (four awaliyah), and Midayatun Ni'mah (four awaliyah). Diniyah Wustho: Muhammad Alif Indra Saputra (three wustho), Nurhidayat (three wustho), Laila Mayangsari (three wustho), and Fitri (two wustho). Diniyah Ulya: Syaifullah (three ulya), Muhammad Wildan (one ulya), Asyiqoh (three ulya), and Nur Faidhiah (two ulya). The data source used in this study, namely the primary data source that is the result of interviews with informants about consumption behavior. Data in this study, researchers act as instruments as well as data collectors. The procedures used in data collection are observation, interviews, and documentation. The data analysis technique used in this study is the Spradley model. The stages consist of domain analysis, taxonomic analysis, componential analysis, and cultural theme analysis [10]. The validity of qualitative research data in this study uses the data credibility test.

\section{RESULTS AND DISCUSSION 3.1. Santri Consumption Behavior in Darussalam Martapura Islamic Boarding School}

From the number of research subjects as many as 12 santri it is known that six of them have wasteful consumption behavior and the other six have frugal consumption behaviors (not excessive).

His findings are consistent with James Duesenberry's consumption theory, according to Duesenberry in his relative income hypothesis states that there is always a tendency for every member of society to increase their consumption once there is an increase in income. Fluctuations in income levels cause consumer (household) behavior to be different in the short and long term. This happens because essentially they do not pay much attention to their absolute level of consumption, as is their relative consumption of members of the community around their environment. If consumers always see the consumption patterns of richer neighboring households, then there is a demonstration effect, but imitation of the neighbor's consumption patterns in the surrounding community. The theory of consumption using the relative income hypothesis was put forward by James Duesenberry with the two assumptions approach used:

a. Household tastes of consumer goods are independent, that is, affected by spending by neighbors.

b. Consumption expenditure is irrevisible. This means that the pattern of expenditure when income rises is different from when income decreases.

Then another factor that can affect public consumption expenditure is consumption expenditure carried out by the community environment, if someone lives in a community that has a high consumption then that person tends to follow the pattern of public consumption with high consumption patterns as well.

So, there is a direct effect (rachet effect), where consumers adjust their consumption slightly due to the current income decline. But these adjustments are not symmetrical because of the increase in relative income, they will immediately 
increase consumption to the highest level ever achieved. Therefore, according to this hypothesis, average consumption and marginal consumption are constant. Both remain the same even though income rises to peak income levels. If current income is smaller than peak income, then the desire for marginal consumption will be less than the average consumption desire. However, the desire for average consumption will increase if current income increases [11].

Another factor that influences consumption expenditure in this theory is consumption expenditure carried out by the community. If someone lives in an environment with a high level of consumption, it tends to follow that pattern, and vice versa. Proving these two assumptions can be seen as follows:

\subsubsection{Environment}

The environment referred to in this study is a description of the students' home environment and their school environment. Based on the results of interviews, researchers found differences between the environment around the homes of santri with the environment in schools. The school environment tends to follow Islamic life, work on obligations and sunna, the joints of life according to Islamic religious rules, being in a city with smooth access, having facilities and infrastructure that is in full. The school environment teaches life not israf (excessive).

In contrast to the home environment of the santri, the conclusion is drawn that the home environment is the same as the village in general. The environment tends to be harmonious, the atmosphere is cool, quiet, and comfortable. The existence of the community in the environment influences the level of expenditure. Neighborhood settlements with a moderate level of density and arrangement of houses tend to gather to make what the neighbors consume will be seen by other neighbors. This tendency affects the expenditure of each family because there is a sense of wanting to have what the neighbors already have. This makes the actual expenditure not to meet needs but desires alone. While female students who live near school environments tend to be religious, the existence of schools in cities with complete facilities makes it easy to buy whatever they want. Even though the environment seems religious, the people in the environment tend to follow the expenses of their neighbors. Ease of access to consume something will facilitate their cxpenditure.

\subsubsection{Social Status}

Explaining one's position in social stratification. Showing santri are in a hierarchical system. Social status (his family's status in society) will influence his daily life to behave. The social status of a family that has a high income will affect the family's expenses. When income rises, spending will also go up. On the personal aspect of santri we can find out the income and expenses they receive each month. It is known that santri with their parents' occupations as farmers, traders, teachers, and entrepreneurs have a grouping of monthly income at high, is on and low levels as follows: classified as high income in the range $(1,570,000$ $1,045,000)$ of five people, classified as moderate income that is a range $(800,000-500,000)$ of two people, and classified as small income that is a range $(465,000-220,000)$ of five people.

The income is divided into several expenses for consumption, housing costs, education costs, and social responsibility costs such as zakat, donation and alms (source of 2020 research data). The types of expenses of the santri are for daily expenditure, monthly expenditure, tuition fees, housing costs, and savings. Daily expenditure includes social responsibility and cultural needs, social needs, personal needs and psychological needs. The conclusion is that the research findings are in accordance with the two assumptions approach, namely independent consumption and irrevisible consumption belonging to James's consumption theory.

\subsection{Santri Comsumption Behavior on the Concept of Planning, Income, Expenditures, and Recording (Priority Scale)}

Santri consumption behavior refers to four concepts, namely the concepts of planning, income, expenditure, and priority scale (recording). The concept of purchase planning is included in the cultural aspect, while the concept of income, the concept of expenditure, and the concept of priority scale (recording) are in the personal aspects of santri. The four concepts can be seen in the following explanation:

\subsubsection{Purchasing Planning}

It is important to measure the extent to which you will buy and use. Purchasing planning can also minimize wasteful attitudes. The following is an overview of the planning of purchases made by santri.

Table 1 Planning to Purchase by Santri

\begin{tabular}{|c|c|c|c|c|c|c|}
\hline \multirow{5}{*}{ Purchasing Plainning } & \multicolumn{6}{|c|}{ Santri } \\
\hline & \multicolumn{3}{|c|}{$\mathrm{L}$} & \multicolumn{3}{|c|}{$P$} \\
\hline & U & W & A & U & $\mathrm{W}$ & A \\
\hline & No & Yes & No & Yes & No & No \\
\hline & No & No & Yes & No & No & Yes \\
\hline
\end{tabular}

Source: proccesd from 2020 research data from the table it apperats that 8 santri did not make any purchase planning

The majority of research subjects do not make a purchase planning based on that if you want to consume something without being planned carefully, but there are also santri who make planning purchases on the grounds that they are 
obliged to make a purchase plan so that they are not excessive.

\subsubsection{Income}

The following is the range of santri income provided by parents and guardians. High income is in the range of
$(1,570,000-1,045,000)$ as many as five people, classified as moderate income is a range $(800,000-500,000)$ as much as two people, and classified as small income is a range $(465,000-220,000)$ as many as five people. The following table illustrates the income for each santri:

Table 2 Santri Income

\begin{tabular}{|c|c|c|c|c|c|c|}
\hline \multirow{3}{*}{ Revenue } & \multicolumn{7}{|c|}{ Santri } \\
\cline { 2 - 7 } & \multicolumn{3}{|c|}{$\mathrm{L}$} & \multicolumn{3}{c|}{$\mathrm{P}$} \\
\cline { 2 - 7 } & $\mathrm{U}$ & $\mathrm{W}$ & $\mathrm{A}$ & $\mathrm{U}$ & $\mathrm{W}$ & $\mathrm{A}$ \\
\cline { 2 - 7 } & 1.570 .00 & 285.000 & 1.045 .000 & 220.000 & 1.150 .000 & 1.665 .000 \\
\cline { 2 - 7 } & 1.200 .000 & 565.000 & 800.000 & 370.000 & 465.000 & 400.000 \\
\hline
\end{tabular}

Source: proccesd from 2020 research data Income received from santri parents will influence the expenditure of santri

\subsubsection{Expenditure}

The following table illustrates expenses for each santri for a month:

Table 3 Santri Expenditure

\begin{tabular}{|c|c|c|c|c|c|c|}
\hline \multirow{5}{*}{ Expenditure } & \multicolumn{6}{|c|}{ Santri } \\
\hline & \multicolumn{3}{|c|}{$\mathrm{L}$} & \multicolumn{3}{|c|}{$\mathrm{P}$} \\
\hline & $\mathrm{U}$ & W & A & $\mathrm{U}$ & W & A \\
\hline & 1.5700 .00 & 285.000 & 1.450 .000 & 150.000 & 1.150 .000 & 1.665 .000 \\
\hline & 1.200 .000 & 565.000 & 800.000 & 300.000 & 400.000 & 400.000 \\
\hline
\end{tabular}

Source: proccesd from 2020 research data data

It can be concluded that the type of expenditure of the santri was for daily expenditure, monthly expenditure, tuition fees, housing costs, and savings. Daily expenditure includes

social responsibility and cultural needs, social needs, personal needs and psychological needs. The higher level of income obtained affects the level of expenditure of santri.

\subsubsection{Recording (Priority Scale)}

A description of the recording (priority scale) made by santri can be seen in the following table:

Table 4 Santri Recording (Priority Scale)

\begin{tabular}{|c|c|c|c|c|c|c|}
\hline \multirow{3}{*}{$\begin{array}{c}\text { Recording (Priority } \\
\text { Scale) }\end{array}$} & \multicolumn{7}{|c|}{ Santri } \\
\cline { 2 - 7 } & \multicolumn{7}{|c|}{ L } & W & A & U & W & A \\
\cline { 2 - 7 } & No & No & Yes & Yes & No & Yes \\
\cline { 2 - 7 } & No & No & No & No & No & Yes \\
\cline { 2 - 7 }
\end{tabular}

Source: proccesd from 2020 research data data

From this table it can be seen that 8 Santri do not make a priority scale (recording) of purchases either daily, weekly, or monthly periods. 4 santri make a priority scale (recording) purchase.

In can be scale (recording) can reduce the wasteful attitude in themselves because all expenses must be in accordance with the recording. While the santri who did not make the priority scale (recording) did admit that they were wasteful, to make the priority scale (recording) feel lazy. These concepts are very important to reduce wasteful consumption behavior for santri, but findings in the field state that a lot of santri do not pay attention to the concept so that santri have consumption behavior which tends to be wasteful.

\subsection{Trends in Santri Consumption Behavior}

vior Consumption behavior can be divided into three types namely Impulsive Buyers are consumers who want to quickly buy, tend to be careless in consuming the products offered. Patient Buyers are conscientious consumers who make price comparisons and analyze the products offered. Window Shoppers are consumers who are just browsing or just surfing.

A description of the trends in santri behavior can be seen in the following table: 
Table 5 Trends in Santri Consumption Behavior

\begin{tabular}{|c|c|c|c|c|c|c|}
\hline \multirow{3}{*}{$\begin{array}{c}\text { Consumption } \\
\text { Behavior }\end{array}$} & \multicolumn{7}{|c|}{ Santri } \\
\cline { 2 - 7 } & \multicolumn{7}{|c|}{ L } & A & U & W & A \\
\cline { 2 - 7 } & $\mathrm{U}$ & $\mathrm{W}$ & $\mathrm{PB}$ & $\mathrm{PB}$ & $\mathrm{PB}$ & $\mathrm{PB}$ \\
\cline { 2 - 7 } & $\mathrm{IB}$ & $\mathrm{PB}$ & $\mathrm{PB}$ & $\mathrm{PB}$ & $\mathrm{PB}$ \\
\cline { 2 - 7 }
\end{tabular}

Source: proccesed from 2020 research data data

*IP (Implusive Buyers)

*PB (Patient Buyers)

From this table, it is known that santri have a tendency to consume consumption behavior. Implusive buyers and patient buyers. In Implusive buyers there are 2 people and in Patient buyers there are 10 people. Based on interviews and observations of santri, there is a tendency for Implusive buyers and Patient buyers due to variations in consumption behavior trends based on the santri individual. Careless and impatient attitude will make a mistake at terminating the purchase. This tendency will affect the consumption behavior of the santri.

\section{CONLUSION}

From the number of research subjects as many as 12 santri it is known that six of them have wasteful consumption behavior and the other six have frugal consumption behaviors (not excessive). James Duesenberry with the two assumptions approach used: First, household tastes on consumer goods are independent, that is, influenced by spending done by neighbors, secondly consumption expenditure is irrevisible. This means that the pattern of expenditure when income rises is different from when income decreases. Proving these two assumptions can be seen as follows: The existence of the community in the environment influences the level of expenditure. Neighborhood settlements with a moderate level of density and arrangement of houses tend to gather to make what the neighbors consume will be seen by other neighbors. This tendency affects the expenditure of each family because there is a sense of wanting to have what the neighbors already have. This makes the actual expenditure not to meet needs but desires alone. While female santri who live near school environments tend to be religious, the existence of schools in cities with complete facilities makes it easy to buy whatever they want. Even though the environment seems religious, the people in the environment tend to follow the expenses of their neighbors. Ease of access to consume something will facilitate their expenditure. Then explain about one's position in social stratification. Showing students are in a hierarchical system. Social status (his family's status in society) will influence his daily life to behave. When income rises, spending will also go up. On the personal aspect of santri we can find out the income and expenses they receive each month. Santri consumption behavior refers to four concepts, namely the concepts of planning, income, expenditure, and recording (priority scale). The concept of purchase planning is included in the cultural aspect, while the concept of income, the concept of expenditure, and the concept of priority scale (recording) are in the personal aspects of santri. These concepts are very important to reduce wasteful consumption behavior for santri, but findings in the field state that a lot of santri do not pay attention to the concept so that santri have consumption behavior which tends to be wasteful. The consumption behavior can be divided into three types namely Impulsive Buyers are consumers who want to quickly buy, tend to be careless in consuming the products offered. Patient Buyers are conscientious consumers who make price comparisons and analyze the products offered. Window Shoppers are consumers who are just browsing or just surfing. This tendency will affect the consumption behavior of the santri.

\section{REFERENCES}

[1] K. E. Case and R. . Fair, Prinsip-prinsip Ekonomi. Jakarta: Erlangga, 2007.

[2] J. F. Engel, Perilaku Konsumen Jilid I. Jakarta: Bina Aksara Rupa, 1994.

[3] E. M. Sangdji and \& Sopiah, Perilaku Konsumen - Pendekatan Praktis disertai. Yogyakarta: C.V Andi, 2013.

[4] Panjul, "E-commerce," 2010.

[5] P. Kotler, Manajemen Pemasaran: Analisis, Perencanaan, Implementasi, dan Kontrol. Jakarta: Prehallindo, 2001.

[6] N. J. Setiadi, Perilaku Konsumen Konsep dan Implikasi untuk Strategi dan Penelitian Pemasaran. Jakarta: Prenada Media, 2003.

[7] A. F. Yasin, Dimensi-dimensi Pendidikan Islam. Malang: UIN Maliki Press, 2008.

[8] Wikipedia, "Pondok Pesantren Darussalam Martapura," 2019. https://id.wikipedia.org/wiki/Pondok\%0A_Pesan tren_Darussalam_Martapura (accessed Jan. 01, 2020).

[9] N. Hidayati, "Pemerintahan Kekhasan Pengajaran Kitab Kuning Pada Pondok Pesantren Darussalam Martapura Kalimantan Selatan (Telaah Aspek Linguistik dan Sosiolingustik)," Madania, vol. 21, no. 1, pp. 1-10, 2017.

[10] Sugiyono, Metode Penelitian Kuantitatif, Kualitatif, dan R\&D. Banadung: Alfabeta, 2019.

[11] M. Sangaji, "Fungsi Konsumsi Rumah Tangga Di Indonesia (Pendekatan Model Koreksi Kesalahan)," J. Indones. Appl. Econ., vol. 3, no. 2, pp. 152-153., 2009, doi: 10.21776/ub.jiae.2009.003.02.2. 